\title{
Excessive Increment in E-Waste System and its Prohibition through Green Computing
}

\author{
Asmita Chawla \\ School Of Information Technology, Mats \\ University, Raipur(C.G)
}

\author{
Jaswinder Kaur \\ School Of Information Technology, Mats \\ University, Raipur(C.G)
}

\begin{abstract}
In the current scenario, the information and communication technology have made drastic changes in our daily routine like industries, institution and almost in each field. In today's world there is a large amount of usage of electronic equipments which are giving rise to many problems. The energy consumption from such devices also leading to various global warming issues. At the same time they are leading to many problems like problems of massive amount 0of hazardous waste and other wastes which are generated from electronic equipment
\end{abstract}

Therefore here we will discuss about various consequences of e-waste , their effects and management of these toxic ad dangerous wastes so as to make the process energy efficient and environment friendly

Keywords- E-waste, Green Computing, Recycling, Dumping, Electronic Waste, 


\section{CATEGORIES OF E-WASTE}

\section{INTRODUCTION}

In the modern era heavy usage of electronic gadgets during the last two decades has led to increment of a huge amount of e-wastes in soil and environmental pollutants. Thus the major concern nowadays is pollution control and environmental safety. Dumping of electronic wastes has become a major problem in our society. Because these wastes are non biodegradable the gradual reposition of these e-wastes leads to increment of various toxic metals like lead cadmium and pollutes the soil and the ground water. Ground water pollution affects the plants, animal and the humans too as a whole causing severe health problems and disorders.

Therefore, proper management of these electronic wastes has become a crucial demand of the time.

\section{E-Waste}

Electronic waste also referred as e-waste describes unwanted electrical or electronic devices. Used electronics which are intended for reuse, resale, salvage, recycling or disposal are also considered as e-waste. Spontaneous processing of electronic waste in all of the countries may cause serious physical and environmental complications, as these countries have limited managerial fault of ewaste processing.

Electronic components such as Cathode Ray Tubes may contain components such as lead, cadmium, beryllium, residents. Even in many countries reprocessing and dumping of e-waste may involve serious risks to the workers and commonality and great care must be taken to avoid uncertain vulnerability in the operations of recycling and leaking of materials such as heavy metals. All other electronic devices $\&$ storage media ${ }^{[1]}$

\section{Green Computing}

Green computing, also termed as green technology, is the environmentally answerable cause of computers and related resources. Such practices include the utilization of energy-efficient central processing units, servers and devices as well as reduced resource consumption and proper dumping of electronic waste (ewaste). ${ }^{[2]}$

Many IT manufacturers and dealers are continuously spending money in designing energy efficient computer devices, reducing the use of harmful materials and supporting the recyclability of digital devices and paper. Green computing practices came into existence in the year 1992, when the Environmental Protection Agency (EPA) launched the Energy Star program. Green computing aims to attain economic energy and improve the way how computing devices are used. Green IT includes the development of environmentally feasible production practices, energy efficient computers and improved disposal and recycling procedures. ${ }^{[3]}$

\begin{tabular}{|l|l|}
\hline $\begin{array}{l}\text { Large Household } \\
\text { Appliances }\end{array}$ & $\begin{array}{l}\text { Washing machines, } \\
\text { Dryers, Refrigerators, } \\
\text { Air-conditioners, etc. }\end{array}$ \\
\hline $\begin{array}{l}\text { Small Household } \\
\text { Appliances }\end{array}$ & $\begin{array}{l}\text { Vacuum cleaners, Coffee } \\
\text { Machines, Irons, } \\
\text { Toasters, etc }\end{array}$ \\
\hline $\begin{array}{l}\text { Office, Information \& } \\
\text { Equmunication }\end{array}$ & $\begin{array}{l}\text { PCs, Laptops, Mobiles, } \\
\text { Telephones, Fax } \\
\text { Machines, Copiers, } \\
\text { Printers etc. }\end{array}$ \\
\hline $\begin{array}{l}\text { Entertainment \& } \\
\text { Consumer Electronics }\end{array}$ & $\begin{array}{l}\text { Televisions, } \\
\text { VCR/DVD/CD players, } \\
\text { Hi-Fi sets, Radios, etc }\end{array}$ \\
\hline Lighting Equipment & $\begin{array}{l}\text { Fluorescent tubes, } \\
\text { sodium lamps etc. } \\
\text { (Except: Bulbs, Halogen } \\
\text { Bulbs) }\end{array}$ \\
\hline $\begin{array}{l}\text { Toys, Leisure, Sports } \\
\text { Equipment }\end{array}$ & $\begin{array}{l}\text { Electric train sets, coin } \\
\text { slot machines, treadmills } \\
\text { etc. }\end{array}$ \\
\hline $\begin{array}{l}\text { Electric and Electronic } \\
\text { Tools }\end{array}$ & $\begin{array}{l}\text { Drills, Electric saws, } \\
\text { Sewing Machines, Lawn } \\
\text { Mowers etc. (Except: } \\
\text { large stationary } \\
\text { tools/machines) }\end{array}$ \\
\hline
\end{tabular}

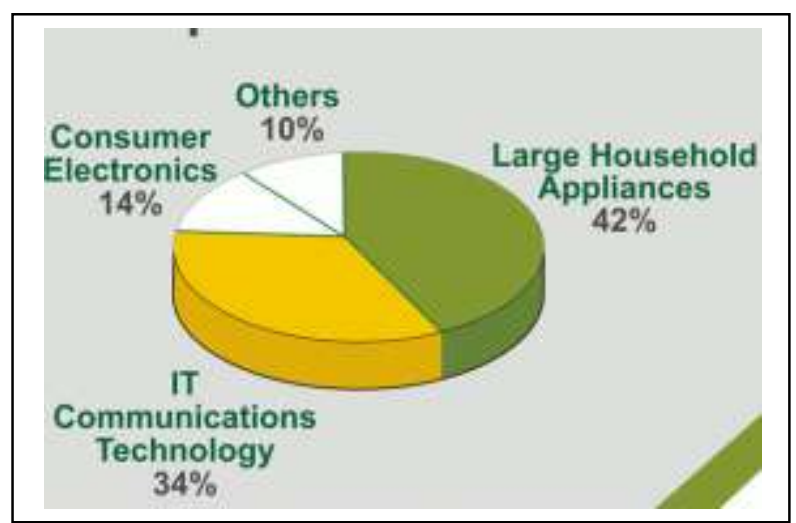

Figure1: Composition of E-Waste[1]

\section{IMPACT ON ENVIRONMENT AND HUMAN HEALTH}

Electronic wastes can cause comprehensive environmental damage due to the use of harmful materials in the compose of electronic goods. In form or the other 
International Journal of Computer Applications Technology and Research

Volume 5- Issue 2, 76 - 82, 2016, ISSN:- 2319-8656

harmful materials such as lead, mercury and hexavalent chromium are present in such wastes which consists of Cathode ray tubes (CRTs), Printed board assemblies, Capacitors, Mercury switches and relays, all kinds of Batteries, Liquid crystal displays abbreviated as LCD, Cartridges of the Photocopy machines, Selenium drumsthe photocopier drums and Electrolyte. It is mainly known as, e-waste contains deadly substances such as Lead and Cadmium which are present in circuit boards; lead oxide and Cadmium present in monitor Cathode Ray Tubes (CRTs), Mercury present in switches and flat screen monitors, Cadmium exists in computer batteries; polychlorinated biphenyls (PCBs) present in capacitors and transformers which are very older, and brominated flame choke off on printed circuit boards, plastic casing, cables and Polyvinyl chloride abbreviated as PVC, cable insulation that discharge highly toxic dioxins and furans when burned to regain Copper from the wires.

All electronic components contain printed circuit boards which are very hazardous because they contain lead, brominated flame retardants (which is typically $5-10 \%$ by weight) and antimony oxide, which is also available as a flame retardant (which is typically 1$2 \%$ by weight). Land filling of e wastes can be pointed towards extracting of lead into the ground water. If the CRT is crumbled and burned, it emits harmful fumes into the air. These products contain several rechargeable batteries, all of which contain toxic substances that can pollute the environment when burnt in incinerators or disposed off in landfills.

The cadmium from one cell phone battery pollutes $600 \mathrm{~m} 3$ of water. The amount of cadmium in landfill sites is authoritative, and considerable lethal contamination is caused by the unavoidable effects of cadmium leaking into the surrounding soil. Because plastics are highly combustible, the wiring board and electronic products contain brominated flame residents, which are clearly damaging to the health of humans and many living organisms as well as surroundings too.

\section{Health Risks}

Recycling of havoc carries health risks if relevant caution is not taken. Workers those who are working with waste which contains chemical and metals may sense a sensitivity to hazardous substances and have major health problems at the range of physical disorderliness, inabilities etc. Toxic exposure even sometimes may become poisonous. Therefore, dumping of healthcare wastes and toxic metal wastes require special attention in order to abstain major health hazards.

\section{PROBLEMS ARISING THROUGH E-WASTE}

With the rapid-advancement in today's society, electronic appliances of all forms have rapidly unify themselves as a necessity in our daily lives. The TV sets that entertain us, to the GPRS that navigate us; from the headphones in our ears, to the, from the cell phones we communicate through, to the computers we work on. Eagerly, we scramble to proudly hold the latest and greatest.[5]

The amount of electronic devices junked globally has increased recently, with 20-50 million tones generated each year.

Electronic waste (e-waste) at present makes up five percent of all municipal solid waste worldwide, nearly the same amount as all plastic packaging does, but it is much more poisonous than that. Not only developed countries produce e-waste, Asia shelve an estimated 12 million tonnes of e-waste every year.

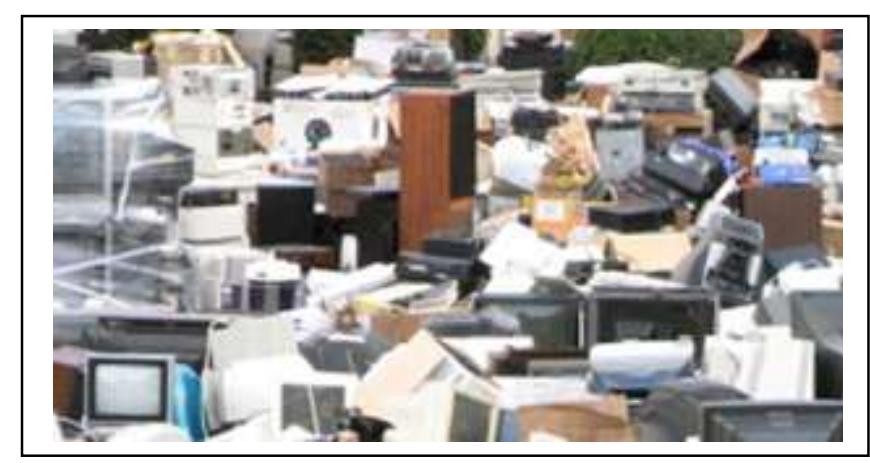

Figure: Showing E-Waste in India

\section{SOURCES OF E-WASTE}

\begin{tabular}{|l|l|}
\hline Home & PC \\
& Television \\
& Radio \\
Cell Phones \\
Microwave Oven \\
Washing Machine \\
& Electronic Iron \\
\hline Hospitals & PC \\
& Monitors \\
& ECG Devices \\
& Microscope \\
Incubator \\
\hline Government
\end{tabular}


International Journal of Computer Applications Technology and Research

Volume 5- Issue 2, 76 - 82, 2016, ISSN:- 2319-8656

\begin{tabular}{|l|l|}
\hline & Air Conditions \\
\hline Private Sectors & PC \\
(Restaurants, & Boiler \\
Industries) & Mixer \\
& Signal Generator \\
& Incubator \\
\hline
\end{tabular}

and old computers and external parts and so it is very complicated to track what measure of imports is used electronic goods ${ }^{[4]}$

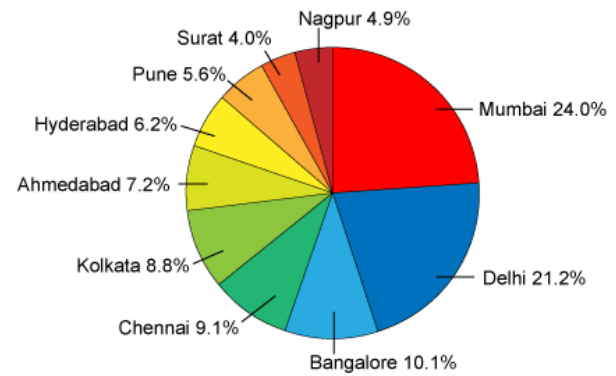

City-wise E-waste Generation in India (Tonnes/year)

As there is no independent collection of e-waste in India, there is no crystal clear data on the quantity developed and dumped on each year and the resulting amount of environmental exposure. The preferred method to get rid of extinct electronic items in India is to get them in interchange from vendors. The business division is estimated to report for $78 \%$ of all installed computers in India. Discarded computers from the business zone are sell-off. Sometimes educational institutes or charitable institutions collect old computers for their reuse. It is estimated that the total number of discarded personal computers emerge each year from business and individual households in India will be around 1.38 million. According to a survey of fraternity of Indian Industries, the total waste generated by discarded or damaged electronic and electrical devices in India has been estimated to be $1,46,000$ tons per year. The results of a field report conducted in the Chennai, a city of India to determine the average usage and life of the personal computers (PCs), television (TV) and cell phones showed that the average homely management of the PC ranges from 0.39 to 1.70 build upon the income class. Television sets ranges from 1.07 to 1.78 and for mobile phones it ranges from 0.88 to 1.70 . The lowincome households use the Computers for 5.94 years, Televisions for 8.16 years and the cell phones for 2.34 years while, the upper income class people uses the Computers for 3.21 years, Television for 5.13 years and cell phones for 1.63 years. Although the per-head waste production in India is still comparatively small, the complete volume of wastes generated will be very high. Further, it is increasing at a faster rate. The growth rate of the mobile phones $(80 \%)$ are very high as compared to that of PC (20\%) and TV (18\%) as people use mobile phones much more than PCs and TVs. The public alertness on e-wastes and the eagerness of public to pay for e-waste management as computed during the study based on an organized census revealed that about $50 \%$ of the public are informed about the environmental and health impacts of the electronic devices. The eagerness of public to pay for e-waste management varies from $3.57 \%$ to $5.92 \%$ of the product cost for Computers, $3.94 \%$ to $5.95 \%$ for TV and $3.4 \%$ to $5 \%$ for the cell phones.

Additionally appreciable quantities of e-waste are reported to be intended. However, no adequate figures available on how generous are these e-waste streams. The government trade data does not categorize between new 

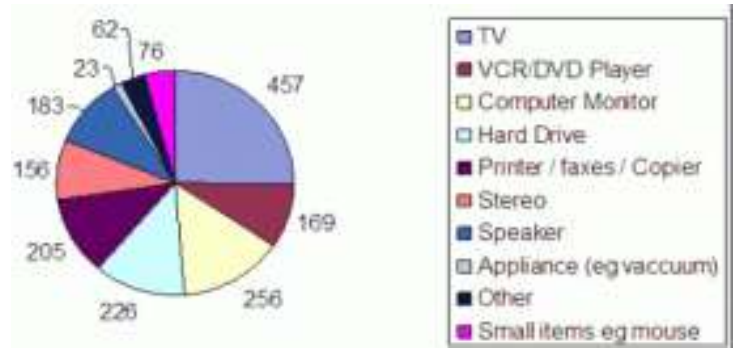

Figure: E-Waste Recycled since 1/8/09 (number of items) ${ }^{[12]}$

\section{FORTHCOMING TRENDS}

The global e-waste production is probably to raise due to the economic development and the available technologies since the increased GDP points to increased buying of electronics and basically increased e-waste manufacture.

The increasing economic growth is expected to replicate higher ewaste production. On the contrary, it is expected that specific changes in the technology and the utilization habits are likely to decrease the worldwide e-waste production, since customers may support more convenient PC solutions having 1-3 kg standard weight compared to the immobile computer weighing $25 \mathrm{~kg}$, or the immobile computers is projected to be prepared with LCD (Liquid Crystal Display) screens instead of the older CRTs (Cathode Ray Tube).[8]

\section{E-WASTE AS INFORMATION SECURITY}

The safety of the information on your electronic devices are the most beneficial issue when choosing an electronics recycler Ewaste presents a possible security risk to individuals and exporting countries. Hard drives that are not correctly erased before the PC is disposed of can be reopened, revealing sensitive information. Credit card numbers, confidential financial data, account details, and records of online dealings can be accessed by most enthusiastic individuals. Ordered criminals usually look up for the drives for information to use in confined scams.

\section{GREEN COMPUTING AN ECO FRIENDLY APPROACH TOWARDS E-WASTE}

Green computing is a fresh technology that is now in attention of business, industries for the energy performance and to dispose E-waste in an effective and risk-free way. They now came to understand that going green is in best interest, both in terms of public affairs and cheap costs. Force of computing was initially on quicker analysis and speedier calculation and solving of more difficult problems. But in the latest past Green computing has got vast importance and that is reaching of energy efficiency, minimization of power utilization of e-equipment.

It has also given highest awareness to minimization of e-waste and use of non-hazardous materials in preparation of resourceful computers and Electronics. The main goal of this technology is to study and apply computing resources efficiently and naturally. Maximizing the energy efficiency and to support biodegradability which are the prime focus of this technology. Due to pollutants generated by it and the regular increment in rates, energy utilization is causing a serious environmental and monetary problems. On the subject of energy efficiency, a branch of Green IT named energyaware computing has emerged. Green computing is very much necessary for the forthcoming world. It is required to make our self as well as our environment healthy and fit. It can be defined as sensibly utilizing the resources presented. Many computers are formed from many poisonous substances like cadmium, mercury and other harmful objects. While disposing off the computers, it will lead to pollution and affect the environment to a greater extent. This field encircles a broad range from new generation techniques to the study of higher materials to be used in our daily life. Bringing it to practice will deal with many problems that are being a risk to human life and our environment too. The impact of the poisonous wastes that are produced by us from throwing our old computers and peripherals which leads to land pollution. The computers have the power hogs that produce pollution by the energy they absorb for their processes.[9]

\section{GREEN COMPUTING SOLUTIONS AS OUR MAJOR GOAL}

\section{Developing sustainable green-computing plans}

This involves active contribution of all the citizens those who are linked with the organisations from the finest levels to the ground level. Organizational policies and catalogues needs to be organized, containing obligatory guidelines, government policies, - greenrecommendation, list of eco-friendly and non-recyclable items. The greatest practices and procedures which should aim at decline of usage of non-conventional resources, by falling usage of paper and recycling of old devices and systems in order to abolish e-wastes from the organizations.

\section{Recycle and Reuse}

Rejected, used or unwanted electronic tools in a convenient and environmentally answerable manner. Computers have contaminant metals and pollutants that can release dangerous emissions in the environment. Computers should never, ever be eliminated in landfills. Recycle them instead through producer programs such as recycling facilities in your society. Or give away still-working computers to a non-profitable organization.

\section{Purchase products which are environmentally green}

Buy products which are labeled as green and safe for you as well as the environment. These products help to reduce the deprivation caused by the energy-consumption to the environment. For these consumers should be motivated to buy products which are environmentally sound. Clear and unblemished criteria must be set for the desire of green-products. Creators should be also involved and given appropriate credits for the process of manufacturing products which are beneficial for the environment. Buy the Electronic Product Environmental Assessment Tool registered products. EPEAT is a acquisition tool promoted by the nonprofit Green Electronics Council. 


\section{Minimizing consumption of paper}

There are many ways to nullify the usage of paper. With computers being more popular than any other thing today all jobs can be done on the accumulator. Complicated modes of communications like email, free-messaging, and other social sites that have brought communication to your approach. Moreover paper is being saved by the industries, as many industries are trying to change themselves to - paper-less-mode day by day.

\section{Conservation of energy}

All electronic devices show the consumption of energy which has been taken from non-renewable energy resources. So adopt the suitable strategy and techniques so as to preserve energy so that it can be recycled when there is the actual need.

\section{FORTHCOMING TRENDS}

The forthcoming trend of Green Computing is going to be based on competence, rather than decrementation in consumption .

The primary focus of Green IT is in the organization's self interest in energy cost decrement, at Data Centers and at desktops too, and the conclusion of which is parallel Reduction in carbon generation. The secondary focus of Green IT needs to be focus ahead of the energy use in the Data Center and the focus should be on modernization and improving arrangement with overall corporate social responsibility efforts. The secondary focus will insist the development of Green Computing strategies. The idea of feasibility addresses the topic of business value formation while ensuring that long-term environmental resources are not affected. There are few efforts, which all companies should take care of

\section{A. Certifications for Green Products}

B. Cloud Computing

C. Product Longevity

D. Power Management tools

E. Leveraging Unused Computer Resource

F. Data Compression

G. Application

\section{ADVANTAGES AND DISADVANTAGES OF GREEN COMPUTING}

\author{
Advantages: \\ - Energy saving \\ - Environmentally Friendly \\ - Cost-effective (pays over time \\ - Save more money per year \\ - can give you a tax right off
}

\section{Disadvantages:}

- High expenditures

- Not readily available

- Still in experimental stages

- Sacrifice performance for battery life

- Not for everyone

\section{CONCLUSION}

"Technology is not a passive observer, but it is an active subscriber in obtaining the goals of Green Computing."

As Consumers we have only taken care of speed, price and performance factors of the electronic appliances and gadgets but the thing which we haven't cared about at all is their ecological impacts. But with the mushrooming concern on environment and surroundings, people have started thinking about safer and greener concepts.

Division of E-waste into specific branches at collection stage is clearly an helpful approach for providing consequent valuable recycling and reuse.

At present various companies have developed many technologies through it can recycle wastes and does not use any chemicals along with it. Efforts are being pushed up by IT sector to achieve green computing by reduction and recycling of resources. The rules and regulations of government are driving dealers to behave green, do green, go green, think green and act green to adopt green computing.

All these efforts are still in process mainly to reduce the E-waste but the future of Green Computing will be depending on efficiency and the green products.

\section{REFERENCES}

[1] https://en.wikipedia.org/wiki/Electronic_waste

[2] http://searchdatacenter.techtarget.com/definition/green-computing

[3] [https://www.techopedia.com/definition/14753/green-computing

[4] [ELECTRONIC WASTE MANAGEMENT IN INDIA-ISSUES AND STRATEGIES KURIAN JOSEPH Centre for Environmental Studies, Anna University, Chennai, India

[5] http://www.imselectronics.com/e-waste-problem/

[6] .http://www.greenpeace.org/international/en/campaigns/detox/electro nics/the-e-waste- problem/

[7] .https://en.wikipedia.org/wiki/Electronic_waste 
International Journal of Computer Applications Technology and Research

Volume 5- Issue 2, 76 - 82, 2016, ISSN:- 2319-8656

[8] E-waste: Environmental Problems and Current Management,G. Gaidajis*, K. Angelakoglou and D. Aktsoglou, Journal of Engineering Science and Technology Review 3 (1) (2010) 193-199

[9] Green Computing: Issues on the Monitor of Personal Computers, A.Mala,, C.UmaRani, L.Ganesan, Research Inventy: International Journal Of Engineering And Science Vol.3, Issue 2 (May 2013), PP 31-36 Issn(e): 2278-4721, Issn(p):2319-6483

[10] Green Computing: From Current to Future Trends, Tariq Rahim Soomro and Muhammad Sarwar, World Academy of Science Engineering and TechnologyInternational Journal of Social, Behavioral, Educational, Economic, Business and Industrial Engineering Vol:6, No:3, 2012

[11]https://www.google.co.in/search?q=e+waste+management+images\&tb $\mathrm{m}=$ isch\&imgil=OJNofjDnNatUoM\%253A\%253B_EFiDtSK8a-

6aM\%253Bhttp $\% 25253 \mathrm{~A} \% 25252 \mathrm{~F} \% 25252 \mathrm{Fe}$ -

wastage. weebly.com $\% 25252 \mathrm{~F} \&$ source $=\mathrm{iu} \& \mathrm{pf}=\mathrm{m} \& \mathrm{fir}=\mathrm{OJN}$ ofjDnNatUoM

$\% 253 \mathrm{~A} \% 252 \mathrm{C}$ EFiDtSK8a-6aM\%252C \&usg= -McDZnTTo3NPU5pkfZOq0hv3QY\%3D\&biw=1517\&bih=741\&dpr=0.9\&ved=0ahUKEwj9zvi2 uL3KAhWNWY4KHVLUCpYQyjcILw\&ei=SCOiVv2KE42zuQTSqKuw CQ\#imgrc=OJNofjDnNatUoM\%3A

[12]https://www.google.co.in/search?q=e+waste+management+images\&tb $\mathrm{m}=$ isch\&imgil=OJNofjDnNatUoM\%253A\%253B_EFiDtSK8a-

6aM\%253Bhttp $\% 25253 \mathrm{~A} \% 25252 \mathrm{~F} \% 25252 \mathrm{Fe}-$

wastage. weebly.com $\% 25252 \mathrm{~F} \&$ source $=\mathrm{iu} \& \mathrm{pf}=\mathrm{m} \& \mathrm{fir}=\mathrm{OJNofjDnNatUoM}$ $\% 253$ A\% 252C_EFiDtSK8a-6aM\%252C_\&usg=_-McDZnTTo3NPU5pkfZOq0hv3QY\%3D\&biw=1517\&bih=741\&dpr=0.9\&ved=0ahUKEwj9zvi2 uL3KAhWNWY4KHVLUCpYQyjcILw\&ei=SCOiVv2KE42zuQTSqKuw CQ\#imgrc=7cqcENnMP2OWdM\%3 